\title{
SECTORAL DIFFERENCES IN DETERMINANTS OF EXPORT INTENSITY
}

\author{
Ciarán MAC AN BHAIRD ${ }^{1}$, Declan CURRAN ${ }^{2}$ \\ ${ }^{1}$ Fiontar, Dublin City University, Dublin 9, Ireland \\ ${ }^{2}$ Dublin City University Business School, Dublin 9, Ireland \\ E-mails: 1'iaran.macanbhaird@dcu.ie (correspondingauthor); ${ }^{2}$ declan.curran@dcu.ie
}

Received 31 July 2014; accepted 03 July 2015

\begin{abstract}
This study investigates firm characteristic determinants of export intensity in small firms. The originality of our approach is a comparative analysis of export intensity between firms in the computer software and manufacturing sectors, using a quasi-maximum likelihood estimation to test for the correct specification of the conditional mean model. Results indicate that larger, younger firms have greater export intensity in the computer software sector than in manufacturing. Research and development expenditure is equally important for export intensity in both sectors, but patent income is not significant. Sourcing managerial advice and expertise from the national development agency is important for firms in the manufacturing industry, but not for computer software firms. It is therefore important for export promotion organisations to publicise supports, as few small firms are aware of their availability. Our findings are especially valuable for policy makers concerned with low levels of export intensity among small firms.
\end{abstract}

Keywords: internationalisation, innovation, export promotion organisations, fractional regression model, computer software, manufacturing.

JEL Classification: F14.

\section{Introduction}

Establishing a presence in international markets through exporting goods and services is important for the growth and sustained development of small and medium sized enterprises (SMEs) (Westhead et al. 2001). Despite the fact that SMEs account for over $60 \%$ of private sector employment and contribute at least half of the Gross Value Added (GVA) in many economies, only a small proportion of SMEs sell goods and services in foreign markets (Bannò et al. 2014). 25\% of European Union (EU27) SMEs are exporters (European Commission 2010) and less than 5\% of US SMEs (USITC 2010). Addressing this dearth of SME export orientation is a priority for policy makers, as witnessed by increased efforts to boost exports through export promotion organisations (EPOs) (Lederman et al. 2010).

Research on SME export determinants and intensity has grown in the past two decades, although these studies have concentrated primarily on the manufacturing sector, with 
empirical studies typically comprising comparative studies between manufacturing activities (e.g. Wagner 2014a) and cross-country differences between manufacturing plants (e.g. Roper, Love 2002). There are relatively few investigations of the export determinants or intensity of services firms (Sousa et al. 2008). This is a considerable omission given the phenomenal growth in services exports over this period (OECD 2011). In Ireland, for example, although the real value of manufacturing exports has remained relatively static since 2000 , the value of services exports has risen by $322 \%$ from $€ 18$ billion to $€ 74$ billion, and accounts for $48 \%$ of exports (Forfás 2011).

Services firms differ significantly from the manufacturing sector in terms of age, size and differences in innovation behaviour (Pires et al. 2008). There are significant differences within the services sector between large scale services such as banking, knowledge intensive services, and smaller scale services (Audretsch et al. 2004). There are also variations between services firms in innovation and technological change (Miles 2005). These differences have implications for exporting and export intensity, and are of particular concern for policy makers seeking to increase export capacity through provision of supports. This paper aims to join to a number of recent studies, such as Wagner (2014b), which has begun the task of addressing this research lacuna. Specifically, we employ firm level data to investigate sectorial differences in export intensity between SMEs, comparing the manufacturing and computer software sectors.

Given that small firms face disadvantages in competing in international markets (Alvarez 2004), due to economies of scale and access to resources (Wagner 2001), policy makers expend considerable resources addressing these issues through the establishment of public support programmes. Data for this study was sourced from a survey of 702 Irish SMEs, consisting of firms with between 20 and 250 employees. This sample size is larger than that of previous studies of export determinants and intensity, for which Sousa et al. (2008) cite a mean of 260 firms. The quantitative methodology employed in this study is the recently developed one-stage fractional probit technique of Ramalho et al. (2011).

The research question addressed in this study is: Are firm characteristic determinants of export intensity in the manufacturing sector different from those in the computer software sector? We also assess the impact of export promotion agencies on export determinants and intensity across sectors. The implication of this research is that, because determinants of export intensity differ between sectors, policy makers seeking to support and promote export activity should design and provide supports geared towards each sector. Our contribution to the literature is thus twofold, as we (a) identify sectoral differences in export intensity, and (b) suggest how EPOs could better target export supports to small firms.

The rest of the paper is structured as follows: in the following section we review the literature and formulate hypotheses. The background to the study and methods of data collection are explained in section 2, and the research methodology is described in section 3. Results are presented and discussed in section 4, and conclusions and policy implications are outlined in the final section. 


\section{Theoretical framework and derivation of hypotheses}

Internationalisation research has developed significantly from early studies which concentrated on multinational firms. Subsequent approaches considered a number of stagemodels, commencing with the Uppsala internationalisation model (Johanson, Vahlne 1977). Further theoretical developments went beyond the stage-model approach, which was considered inadequate to explain phenomena such as the emergence of 'born global' firms (Zahra 2005). Academic studies may be broadly categorised in two distinct but not unrelated strands grounded in "the entrepreneurship literature" and economics literature respectively. The former concerns the process of internationalisation, and it emerged from studies investigating SMEs seeking to export shortly after establishment. These "International New Ventures" do not proceed through a number of stages as theorised by previous approaches, but endeavour to "...derive competitive advantage from the use of resources and the sale of outputs in multiple countries from inception..." (Oviatt, McDougall 1994: 49). Internationalisation studies emanating from the microeconomics literature focus on firm characteristics as determinants of export activity and intensity, along with the effect of exporting on innovation and performance. Evidence suggests a number of firm characteristics influence the propensity of a firm to export, and its export intensity (Raff, Wagner 2014).

We adopt this approach in conducting a comparative study of export intensity, examining determinants of export intensity, rather than the process of internationalisation. Crucially, we consider firm characteristics for both manufacturing and services firms, and explore whether these characteristics have different impacts. We now look in more detail at the firm characteristics identified in this literature, in formulating hypotheses which we will test for both the services and manufacturing sectors.

Larger firms have more resources with which to enter foreign markets (Roper, Love 2002), and have greater capacity to overcome sunk costs associated with foreign market entry (Ottaviano, Volpe Martincus 2011) such as information gathering or establishing a distribution network (Wagner 2014c). Larger firms also have more opportunities to raise finance, and are expected to have more technological resources available (Harris, Li 2009).

Self-selection of larger, more productive firms may be less prevalent among services exporters than their manufacturing counterparts. Eickelpasch and Vogel (2009) note that capital intensity as an indicator of firm assets, embodying past innovations and capturing economies of scale, is expected to have a positive effect. Services firms, particularly knowledge-based ones, may be relatively less capital intensive than manufacturing firms.

H1: Export intensity is positively related with firm size, and this effect is greater for manufacturing firms than computer software firms, ceteris paribus.

Love and Mansury (2009) note a lack of consensus regarding the role of firm age on export propensity. On one hand, older firms have had more time to establish and expand distribution networks, as well as gain a share of export markets. On the other hand, older firms may experience inertia and inflexibility in the face of changing market conditions 
(Contractor et al. 2007). Roper et al (2006) find high export propensity among younger Irish manufacturing firms, although Majocchi et al (2005) report that age is positively associated with export intensity for Italian SMEs. Eickelpasch and Vogel (2009) also point to the incremental process of internationalisation, where firms first enter markets that are similar to their home market, as well as the importance of internal firm resources such as management strategies and characteristics as potential determinants of a firm's export performance.

Firms in the manufacturing sector are generally older than firms in the services sector (Berggren et al. 2000). Additionally, the "age effect" for manufacturing firms may be greater than services firms due to time required for product development and establishment of distribution networks. Therefore, we hypothesise that:

H2: Export intensity is negatively related with firm age, and this relationship is of greater magnitude for firms in the computer software sector than manufacturing firms.

Early studies investigating the effect of innovation on exporting at the firm level use the level of R\&D expenditure as a proxy for innovation. Recent studies take a more nuanced approach, and a number of measures of innovation are now employed (Lefebvre et al. 1998). We use two measures of innovation, an input variable (R\&D expenditure) and an output variable (patent income). Innovation as measured by internal R\&D expenditure or innovative products has a positive effect on exports, both in manufacturing (Roper, Love 2002), and services (Fryges et al. 2014). Firms that invest in product improvement (Ottaviano, Volpe Martincus 2011), and in internal R\&D (Ganotakis, Love 2011) have a competitive advantage over their peers and are more likely to enter foreign markets. Similar to Roper and Love (2002: 1093), we argue that R\&D expenditure is “.... an indicator of investment in the resource base of the plant". As innovation has been found to positively influence the probability of exporting in business services (Love et al. 2010) and manufacturing sectors (Roper, Love 2002), we do not propose sectoral differences in the effects of R\&D expenditure on export intensity.

Anón Higón and Driffield (2011: 6) highlight the need to “...measure innovation more carefully than simply through R\&D spend...". Studies have modelled the propensity to innovate employing a lagged variable, or the innovation history of firms, and Wakelin (1998) finds that the number of past innovations is positively related with exporting. Indicators of past innovation include whether firms have created and developed incomegenerating patents. Consistent with this evidence, we hypothesise that:

H3: Export intensity is positively related with expenditure on research and development and with income from patents.

Studies also investigate the role of export promotion organisations in the internationalisation of new firms (O'Gorman, Evers 2011), and in deploying export promotion instruments (Hayakawa et al. 2014). These studies highlight the role of government agencies in supporting exporting SMEs, especially mediation and information gathering, identifying opportunities and potential customers, and expanding export capacity. In proposing a positive relationship between export intensity and advice from a government development agency, we employ the variable 'receipt of managerial advice and expertise' from the national agency for enterprise development. This advice is not 
specifically related to exporting per se, but is more a measure of 'outward orientation', as SMEs rely primarily on internal resources for advice and expertise.

It is not apparent whether receipt of managerial advice and expertise from the national enterprise agency has a proportionately greater effect on export intensity in either sector. It may be argued that this expertise has a larger effect for manufacturing firms because, as they are older, there is a greater likelihood that they will have approached the national development agency for advice and assistance. On the other hand, Barry and Van Egeraat (2008) attribute the stellar growth of the indigenous software sector to the intensive supportive role played by Enterprise Ireland. On the balance of evidence we propose that:

H4: Export intensity is positively related with receipt of managerial advice from a national development agency, and this relationship is of greater magnitude for manufacturing firms than firms in the computer software sector.

\section{Background and data collection}

In common with other small, open economies, the Irish economy is highly internationalised, as the value of exports and imports amount to $137 \%$ and $103 \%$ of Gross National Product respectively (Central Statistics Office 2013a,b). Although foreign owned multinationals produce the bulk of services and manufacturing exports, Irish owned SMEs produce $7 \%$ of total exports in these sectors, which amounts to $7 \%$ of GVA (Lawless et al. 2014). The importance of indigenous exporting SMEs for employment is even more significant, as they account for $23.5 \%$ of employment in the manufacturing sector, which is double that of foreign exporting SMEs (Lawless et al. 2014). Similarly in the services sector, employment in indigenous exporting SMEs is more than twice that of their foreign counterparts (ibid). Internationalisation is established longer in the manufacturing sector, as the Irish industrial landscape is influenced by an economic development policy of pursuing Foreign Direct Investment (FDI), which initially focussed on attracting manufacturing plants (Ó Gráda 1997). Investment from international services is increasing in importance, and this sector now accounts for $50 \%$ of exports (Central Statistics Office 2013a). Whilst this growth can be largely attributed to foreign multinationals, there have been important overflows to indigenous entrepreneurship, particularly in the computer software sector (Acs et al. 2007). Computer software and services exports have grown from $€ 6$ bn in 2000 to $€ 32$ bn in 2011 , representing over $40 \%$ of services exports (Irish Exporters Association 2011). Whilst a large proportion of these exports are accounted for by multinational firms, a substantial indigenous industry has emerged in parallel (Barry, Van Egeraat 2008).

Data for this study was sourced from a survey of SMEs in the Republic of Ireland, consisting of firms with between 20 and 250 employees. The original database of 1,502 firms was substantially cleaned to remove non-independent enterprises, along with companies in the financial sector. The questionnaire instrument was distributed to the remaining 702 firms using a multimodal approach. This methodology yielded 299 responses, representing a response rate of over $42 \%$. A detailed profile of respondents is provided in Table 1. 
Table 1. Size, export activity, and sectorial classification of respondents $(n=299)$

\begin{tabular}{|c|c|c|c|c|c|}
\hline \multicolumn{2}{|c|}{ Section A. } & \multicolumn{2}{|c|}{ Section B. } & \multicolumn{2}{|c|}{ Section C. } \\
\hline $\begin{array}{l}\text { Firm size } \\
\text { (Gross sales } \\
\text { turnover) }\end{array}$ & $\begin{array}{l}\text { Proportion } \\
\text { of } \\
\text { sample }(\%)\end{array}$ & $\begin{array}{l}\text { Foreign sales } \\
\text { (as a \% of } \\
\text { turnover) }\end{array}$ & $\begin{array}{l}\text { Proportion } \\
\text { of } \\
\text { sample }(\%)\end{array}$ & $\begin{array}{c}\text { Sectorial } \\
\text { classification }\end{array}$ & $\begin{array}{l}\text { Proportion } \\
\text { of } \\
\text { sample }(\%)\end{array}$ \\
\hline$<€ 1 \mathrm{~m}$ & 3.1 & 0 & 27.3 & $\begin{array}{l}\text { Metal } \\
\text { manufacturing } \\
\text { and engineering }\end{array}$ & 15.6 \\
\hline$€ 1 \mathrm{~m}-€ 2.99 \mathrm{~m}$ & 11.6 & $<10 \%$ & 25.6 & $\begin{array}{l}\text { Other } \\
\text { manufacturing }\end{array}$ & 21.3 \\
\hline$€ 3 \mathrm{~m}-€ 4.99 \mathrm{~m}$ & 13.3 & $11-25 \%$ & 10.2 & $\begin{array}{l}\text { Computer software } \\
\text { development }\end{array}$ & 17.3 \\
\hline$€ 5 \mathrm{~m}-€ 9.99 \mathrm{~m}$ & 31.6 & $26-50 \%$ & 9.9 & $\begin{array}{l}\text { Distribution, retail, } \\
\text { hotels and catering }\end{array}$ & 27.5 \\
\hline$€ 10 \mathrm{~m}-€ 20 \mathrm{~m}$ & 32.0 & $51-75 \%$ & 8.9 & Other services & 9.1 \\
\hline$€ 20 \mathrm{~m}-€ 50 \mathrm{~m}$ & 8.5 & $>75 \%$ & 18.1 & Other & 9.2 \\
\hline
\end{tabular}

Exporters account for almost three quarters of the sample, which is significantly more than previous studies (e.g. Ottaviano, Volpe Martincus 2011). Firms in manufacturing and computer software have a significantly greater proportion of export revenue than firms in other sectors.

\section{Research methodology}

There has been a significant shift in the methodological approach applied in studies investigating export determination and intensity. Earlier studies followed a two-step approach (e.g. Gourlay et al. 2005). Wagner (2001: 230) states that this is imperfect, as exporting is “...not a two-step decision - to export or not, and then how much to export”. He applies a one-step approach, in which all observations (both exporters and non-exporters) are included in estimating the model. This is appropriate as a large number of firms do not export at all (Wakelin 1998), and “...observations at the boundaries of a fractional variable are a natural consequence of individual choices and not of any type of censoring ..." (Ramalho et al. 2011: 22). For this reason we concur with Wagner (2001) that exporting and export intensity is not a two-step process, and we adopt a one-step approach.

Linear models are inappropriate when investigating how exogenous variables influence a fractional response variable (e.g. Ramalho et al. 2011). The fractional logit estimator of Papke and Wooldridge (1996) is more appropriate for a fractional response variable of this nature when using cross sectional data, and has been used in a number of studies (Eickelpasch, Vogel 2009). The dependent variable in the present study is fractional, and was collected in interval form. We select the mid-point of each interval in running the fractional response models. Similar to Ramalho et al. (2011), we consider only quasimaximum likelihood (QML) estimation as it outperforms all non-linear least squares 
(NLS) estimators. As the fractional response variable is not continuous, we also run a number of interval regression models and an Oprobit model, results of which are available from the authors on request. The signs and significance of variables in all methods are the same, and regression coefficients are broadly similar. The basic model tested is represented by:

$$
\mathrm{Y}=\beta_{0}+\beta_{1} S I Z E+\beta_{2} A G E+\beta_{3} R \& D E X P+\beta_{4} P A T E N T+\beta_{4} E I A D V I C E+\varepsilon .
$$

Additional models were estimated to test for inter-industry differences employing dummy variables:

$\mathrm{Y}=\beta_{0}+\beta_{1} S I Z E+\beta_{2} A G E+\beta_{3} R \& D E X P+\beta_{4} P A T E N T+\beta_{4} E I A D V I C E+\beta_{7} M E T A L+$ $\beta_{8} M F C T+\beta_{9}$ SERVS $+\beta_{10}$ COMPUTER $+\beta_{11}$ OTHER $+\varepsilon$.

A description of variables tested in each model is presented in Table 2, along with summary statistics. Following Ramalho et al. (2011), Logit, Probit, Loglog and Cloglog models were estimated. These nonlinear models use the logistic, standard normal, extreme maximum, and extreme minimum distribution functions respectively.

Table 2. Description of variables employed in regression models

\begin{tabular}{llccc}
\hline \multicolumn{1}{c}{ Variable } & \multicolumn{1}{c}{ Description of variable } & N & Mean & St. dev. \\
\hline EXPORT & Export sales as a percentage of turnover (categorical & 299 & 0.278 & 0.335 \\
INTENSITY & variable $0 \%, 5 \%, 18 \%, 38 \%, 63 \%, 88 \%$ ). & & & \\
\hline SIZE & Gross sales turnover of the firm (categorical variable) & 294 & 4.034 & 1.238 \\
\hline AGE & $\begin{array}{l}\text { Age of the firm in years at the time of the survey } \\
\text { (categorical variable) }\end{array}$ & 297 & 4.252 & 1.658 \\
& $\begin{array}{l}\text { Research and development expenditure expressed as a } \\
\text { percentage of turnover (categorical variable) }\end{array}$ & 287 & 1.868 & 0.817 \\
\hline \multirow{2}{*}{ \&DD } & Income from patents (binary variable, 0 = no, 1 = yes). & 299 & 0.064 & 0.244 \\
\hline EATENTS & $\begin{array}{l}\text { Management advice and expertise received from } \\
\text { enterprise Ireland (binary variable, 0 = no, 1 = yes). }\end{array}$ & 299 & 0.097 & 0.296 \\
\hline INDUSTRY & Manufacturing (MFCT) & 110 & 0.365 & 0.482 \\
\cline { 2 - 5 } SECTORS & Computer software development (COMPUTER) & 52 & 0.171 & 0.376 \\
\cline { 2 - 5 } & Other services (SERVS) & 27 & 0.090 & 0.287 \\
\cline { 2 - 5 } & Other (OTHER). & 0.090 & 0.287 \\
\hline
\end{tabular}

\section{Results}

Results for four specifications of one-part fractional regression models for the total sample are presented in Table 3. The direction and significance of coefficients for all models is similar, with the exception of patent income which is only significant for the Cloglog model. Although the dependent variable used in the fractional regression models is not continuous, comparison with the results of interval regression models indicates 
that the fractional regression approach is an appropriate methodology. The retest tests indicate that all specifications are acceptable, apart from the Cloglog model for the total sample, which is rejected at the $5 \%$ level.

Coefficients for the variable size are statistically significant in all cases, supporting the stylised finding that firm size and export intensity are positively related. Further tests conducted by interacting size with all other independent variables confirm this effect. Negative relationships between firm age and export intensity are significant for all models, supporting hypothesis 2 and providing first time evidence of this relationship for exporting Irish SMEs. There is also a strong positive relationship between expenditure on $R \& D$ and export intensity.

Table 3. Intensity of exporters: quasi-maximum likelihood models regression results

\begin{tabular}{|c|c|c|c|c|}
\hline \multirow{2}{*}{$\begin{array}{l}\text { Independent } \\
\text { variables }\end{array}$} & \multicolumn{4}{|c|}{ Quasi-maximum likelihood models (QML)* } \\
\hline & Logit & Probit & $\log \log$ & Cloglog \\
\hline SIZE & $\begin{array}{c}.249 * * * \\
(.086)[.004]\end{array}$ & $\begin{array}{c}.141 * * \\
(.049)[.004]\end{array}$ & $\begin{array}{c}.125^{* *} \\
(.047)[.008]\end{array}$ & $\begin{array}{c}.189 * * * \\
(.065)[.004]\end{array}$ \\
\hline AGE & $\begin{array}{c}-.183 * * \\
(.068)[.007]\end{array}$ & $\begin{array}{c}-.107 * * \\
(.039)[.006]\end{array}$ & $\begin{array}{c}-.104 * * * \\
(.038)[.006]\end{array}$ & $\begin{array}{c}-.128 * * \\
(.052)[.014]\end{array}$ \\
\hline R\&D EXP & $\begin{array}{c}857 * * * \\
(.166)[.000] \\
\end{array}$ & $\begin{array}{c}.496 * * * \\
(.090)[.000]\end{array}$ & $\begin{array}{c}.502 * * * \\
(.085)[.000] \\
\end{array}$ & $\begin{array}{c}.573^{* * *} \\
(.109)[.000] \\
\end{array}$ \\
\hline PATENT & $\begin{array}{c}.484 \\
(.360)[.179]\end{array}$ & $\begin{array}{c}.310 \\
(.218)[.155]\end{array}$ & $\begin{array}{c}.346 \\
(.260)[.184]\end{array}$ & $\begin{array}{c}405^{*} \\
(.229)[.077]\end{array}$ \\
\hline EIADVICE & $\begin{array}{c}.605 * * \\
(.309)[.050]\end{array}$ & $\begin{array}{c}.368 * * \\
(.186)[.048]\end{array}$ & $\begin{array}{c}.354^{*} \\
(.215)[.099]\end{array}$ & $\begin{array}{c}.508 * * * \\
(.203)[.012]\end{array}$ \\
\hline MANUFACT & $\begin{array}{c}1.289 * * * \\
(.281)[.000]\end{array}$ & $\begin{array}{c}.730 * * * \\
(.154)[.000]\end{array}$ & $\begin{array}{c}.636 * * * \\
(.136)[.000]\end{array}$ & $\begin{array}{c}1.087 * * * \\
(.248)[.000]\end{array}$ \\
\hline SERVS & $\begin{array}{c}-.282 \\
(.528)[.594]\end{array}$ & $\begin{array}{c}-.115 \\
(.276)[.677]\end{array}$ & $\begin{array}{c}-.047 \\
(.224)[.833]\end{array}$ & $\begin{array}{c}-.309 \\
(.490)[.528]\end{array}$ \\
\hline COMPUTER & $\begin{array}{c}1.086 * * * \\
(.348)[.002]\end{array}$ & $\begin{array}{c}.629 * * * \\
(.194)[.001]\end{array}$ & $\begin{array}{c}.575 * * * \\
(.177)[.001]\end{array}$ & $\begin{array}{c}.977 * * * \\
(.300)[.001] \\
\end{array}$ \\
\hline OTHER & $\begin{array}{c}.684^{*} \\
(.409)[.095]\end{array}$ & $\begin{array}{c}.353 \\
(.240)[.142]\end{array}$ & $\begin{array}{c}.204 \\
(.212)[.337]\end{array}$ & $\begin{array}{c}.733 * * \\
(.363)[.043]\end{array}$ \\
\hline Constant & $\begin{array}{c}-3.796 * * * \\
(.689)[.000]\end{array}$ & $\begin{array}{c}-2.195 * * * \\
(.383)[.000]\end{array}$ & $\begin{array}{c}-1.695 * * * \\
(.352)[.000]\end{array}$ & $\begin{array}{c}-3.324 * * * \\
(.530)[.000] \\
\end{array}$ \\
\hline $\mathrm{R}^{2}$ & 0.3646 & 0.3633 & 0.3633 & 0.3554 \\
\hline Log pseudolikelihood & -115.200 & -115.267 & -115.199 & -116.238 \\
\hline $\mathrm{N}$ & 285 & 285 & 285 & 285 \\
\hline RESET Test (LM2) & .250 & .409 & .556 & $.040 * *$ \\
\hline
\end{tabular}

Notes: $* * * * *$ and $*$ denote significance at the $1 \%, 5 \%$ and $10 \%$ levels respectively. Standard errors and $p$ values are reported below the coefficients in round and square brackets respectively. $P$ values are reported for the RESET test. 
By contrast, the positive relationship between innovation outputs (patent income) and export intensity is insignificant for all models. This evidence only partially supports hypothesis 3, which is rejected. Export intensity is also positively related with receiving managerial advice and expertise from Enterprise Ireland, the national government agency for supporting Irish businesses. In summary, firms with greater export intensity are larger, invest more in innovative activities, and are more 'outward looking' in seeking managerial advice and expertise from the national development agency.

Table 4. Intensity of exporters: fractional regression results (Computer software development)

\begin{tabular}{|c|c|c|c|c|}
\hline \multirow{2}{*}{$\begin{array}{l}\text { Independent } \\
\text { variables }\end{array}$} & \multicolumn{4}{|c|}{ Quasi-maximum likelihood models (QML)* } \\
\hline & Logit & Probit & Loglog & Cloglog \\
\hline SIZE & $\begin{array}{c}.530 * * * \\
(.153)[.001]\end{array}$ & $\begin{array}{c}.320 * * * \\
(.090)[.000]\end{array}$ & $\begin{array}{c}.364 * * * \\
(.095)[.000]\end{array}$ & $\begin{array}{c}.356 * * * \\
(.109)[.001]\end{array}$ \\
\hline AGE & $\begin{array}{c}-.326^{* *} \\
(.164)[.048]\end{array}$ & $\begin{array}{c}-.188 * * \\
(.096)[.050]\end{array}$ & $\begin{array}{c}-.183 * \\
(.097)[.059]\end{array}$ & $\begin{array}{c}-.218 * \\
(.124)[.078]\end{array}$ \\
\hline R\&D EXP & $\begin{array}{c}.818 * * * \\
(.197)[.000]\end{array}$ & $\begin{array}{c}.495 * * * \\
(.116)[.000]\end{array}$ & $\begin{array}{c}.582 * * * \\
(.140)[.000]\end{array}$ & $\begin{array}{c}.537 * * * \\
(.133)[.000]\end{array}$ \\
\hline PATENT & $\begin{array}{c}-.224 \\
(.469)[.632]\end{array}$ & $\begin{array}{c}-.144 \\
(.295)[.626]\end{array}$ & $\begin{array}{c}-.311 \\
(.346)[.369]\end{array}$ & $\begin{array}{c}-.036 \\
(.329)[.913]\end{array}$ \\
\hline EIADVICE & $\begin{array}{c}.135 \\
(.485)[.780]\end{array}$ & $\begin{array}{c}.084 \\
(.295)[.777]\end{array}$ & $\begin{array}{c}-.017 \\
(.362)[.962]\end{array}$ & $\begin{array}{c}.178 \\
(.300)[.554]\end{array}$ \\
\hline Constant & $\begin{array}{c}-3.005 * * * \\
(1.058)[.005]\end{array}$ & $\begin{array}{c}-1.839 * * * \\
(.635)[.004]\end{array}$ & $\begin{array}{c}-1.763 * * \\
(.668)[.008]\end{array}$ & $\begin{array}{c}-2.439 * * * \\
(.816)[.003]\end{array}$ \\
\hline $\mathrm{R}^{2}$ & 0.4190 & 0.4181 & 0.4197 & 0.4089 \\
\hline Log pseudolikelihood & -22.82 & -22.840 & -22.785 & -23.028 \\
\hline $\mathrm{N}$ & 50 & 50 & 50 & 50 \\
\hline RESET Test (LM2) & .508 & .527 & .994 & .243 \\
\hline
\end{tabular}

Notes: $* * *, * *$ and $*$ denote significance at the $1 \%, 5 \%$ and $10 \%$ levels respectively. Standard errors and $p$ values are reported below the coefficients in round and square brackets respectively. $P$ values are reported for the RESET test.

A preliminary investigation of sectoral differences was conducted using dummy variables. Firms in the internationally traded sectors have greater export intensity than firms in the reference sector, "distribution, retail, hotels and catering". This result holds for all models. Firms in the 'other' sector also have a higher intensity of exporting, but this result is not significant for all. Results for firms in the "other services" sector, which are predominantly focussed on the local market, are negative and insignificant.

A more detailed examination of sectoral differences estimates the basic regression specification separately for the manufacturing and computer software sectors. Results presented in Tables 4 and 5 indicate that although the direction of most coefficients is similar, and the same as models for the total sample, there are differences in the size and significance of coefficients between the two sectors. 
Table 5. Intensity of exporters: fractional regression results (Manufacturing)

\begin{tabular}{lcccc}
\hline \multirow{2}{*}{$\begin{array}{c}\text { Independent } \\
\text { Variables }\end{array}$} & \multicolumn{3}{c}{ Quasi-maximum likelihood models (QML)* } \\
\cline { 2 - 5 } SIZE & $.244^{* *}$ & Probit & Loglog & Cloglog \\
\hline AGE & $(.139)[.080]$ & $(.084)[.088]$ & $(.084)[.129]$ & $(.109)[.063]$ \\
\hline R\&D EXP & -.105 & -.067 & -.093 & -.065 \\
& $.799)[.290]$ & $(.060)[.263]$ & $(.068)[.171]$ & $(.071)[.359]$ \\
\hline PATENT & $(.334)[.024]$ & $(.185)[.015]$ & $(.201)[.009]$ & $(.190)[.010]$ \\
\hline EIADVICE & .535 & .344 & -.336 & $.462^{*}$ \\
& $(.442)[.226]$ & $(.276)[.213]$ & $(.347)[.332]$ & $(.287)[.108]$ \\
\hline Constant & $.803 * *$ & $.494 * *$ & $.516^{*}$ & $.639^{* *}$ \\
& $(.405)[.047]$ & $(.247)[.046]$ & $(.288)[.073]$ & $(.277)[.021]$ \\
\hline $\mathrm{R}^{2}$ & $-2.685^{* *}$ & $-1.589 * * *$ & $-1.192^{* *}$ & $-2.423 * * *$ \\
\hline Log pseudolikelihood & $(1.135)[.018]$ & $(.656)[.015]$ & $(.669)[.075]$ & $(.771)[.002]$ \\
\hline $\mathrm{N}$ & 0.1786 & 0.1785 & 0.1828 & 0.1728 \\
\hline RESET Test (LM2) & .53 .854 & -53.834 & -53.588 & -54.072 \\
\hline
\end{tabular}

Notes: ${ }^{* * *}, * *$ and $*$ denote significance at the $1 \%, 5 \%$ and $10 \%$ levels respectively. Standard errors and $p$ values are reported below the coefficients in round and square brackets respectively. $P$ values are reported for the RESET test.

The effect of firm size on export intensity is greater for firms in the computer software sector than in manufacturing, leading us to reject hypothesis 1 . Firm age is a significant determinant of exporting for firms in the computer software sector, but not in manufacturing. Expenditure on R\&D is positively related with export intensity for both sectors, and is equally important for both. By contrast, patent income is not a significant determinant of export intensity for either sector. Finally, receiving advice from the national development agency is positively related with greater export intensity for manufacturing firms, but is insignificant for firms in the computer software sector. This suggests that manufacturing firms may face greater barriers in exporting than services firms, ceteris paribus.

\section{Discussion}

The age effect is stronger for firms in the computer software sector than for the manufacturing sectors and the whole sample. This is consistent with the behaviour of knowledge based firms internationalising from an early stage (Knight, Cavusgil 2005), and indicates that, despite a lack of resources typical of young firms, knowledge based firms in the services sector have fewer barriers to exporting and greater ease of access to for- 
eign markets than manufacturing firms. This result is also consistent with the finding of Berggren et al. (2000), that manufacturing firms are on average 15 years older than service firms when evaluated at the median.

The pervasive positive effect of firm size on export intensity confirms that larger firms have greater resources available to invest in export activities (Harris, Li 2009), and have greater capacity to absorb sunk costs related to exporting (Ottaviano, Volpe Martincus 2011). We find the size effect is greater for firms in the computer software sector than for manufacturing firms. This is congruent with the implication that knowledge intensive firms require relatively less investment than capital intensive firms (Love, Mansury 2009), and can overcome barriers to entering foreign markets more easily (Contractor et al. 2003). Additionally, large firms in the computer software sector operating in countries with a small domestic market need to achieve high export intensity in order to grow.

We investigate the effect of innovation on export intensity on two levels, considering inputs (R\&D expenditure) and outputs (patent income). We find a positive relationship between $R \& D$ expenditure and export intensity, which supports the technology-based model of export performance (Ganotakis, Love 2011). This confirms the result of Roper et al. (2006), who report a strong R\&D effect for indigenously owned manufacturing plants. We explore the 'learning-by-exporting' effect (Harris, Li 2009) by including an innovation "output" variable, patent income. Our findings do not support causation from exporting to innovation, although this may be an imperfect measure of past innovation. Overall, our results indicate the importance of investment in R\&D and innovation for firms in seeking to gain competitive advantage by developing unique inimitable products and processes.

We find that receiving managerial advice and expertise from the national development agency has a positive effect on export intensity for manufacturing firms and the total sample. Lack of significance for exporting firms in the computer software sector suggests that they rely on internal or alternative external sources. This finding indicates that national development agencies have an important role to play in supporting exporting firms, and highlights the need for national governments seeking to develop a strong indigenous exporting sector to invest in these services, particularly in light of the lower export propensity of small firms (Roper et al. 2006).

\section{Conclusions}

Investigating export intensity of a large sample of independent SMEs, we confirm a number of stylised findings about influential firm characteristics, as well as identifying factors not previously tested. In summary, firm age, size, and R\&D expenditure are important, but so also is "outward looking" orientation, specifically the source of external managerial advice and expertise. This support is important for SMEs seeking to grow through exporting, particularly for resource constrained firms with no experience in international trade. This finding is also relevant for policy makers promoting export strategies to indigenous firms, as a recent European Commission study indicates that 
only $10 \%$ of "non-internationally" active and $22 \%$ of "internationally active" SMEs are aware of the export supports available. We also examine differences in characteristics of exporting firms in the manufacturing and computer software sectors. Results indicate that policy makers can use firm characteristics to identify enterprises that face barriers to internationalisation, and should provide distinctive supports and services to each sector rather than adopting a uniform approach. Policy makers can thus improve the return on EPO investment by targeting supports more effectively. In contrast with previous studies suggesting segmentation of supports based on owners' experience, we propose a sectoral approach.

A limitation of our study is that use of a cross-sectional dataset does not facilitate analysis of temporal or sequential effects, including firm-level effects of productivity and profitability. We do not account for the "entry and exit" nature of exporters, although Gleeson and Ruane (2006) highlight the 'persistence' of Irish exporters. Directions for future research include a cross-country investigation of the effectiveness of export promotion programmes, and a multi-factor exploration of the "learning by exporting" effect.

\section{References}

Acs, Z.; O'Gorman, C.; Szerb, L.; Terjesen, S. 2007. Could the Irish miracle be repeated in Hungary?, Small Business Economics 28(2-3): 123-142.

http://dx.doi.org/10.1007/s11187-006-9027-9

Alvarez, R. 2004. Sources of export success in small- and medium-sized enterprises: the impact of public programs, International Business Review 13(3): 383-400.

http://dx.doi.org/10.1016/j.ibusrev.2004.01.002

Anón Higón, D.; Driffield, N. 2011. Exporting and innovation performance: analysis of the annual small business survey in the UK, International Small Business Journal 29(4): 4-24.

http://dx.doi.org/10.1177/0266242610369742

Audretsch, D. B.; Klomp, L.; Santarelli, E.; Thurik, A.R. 2004. Gibrat's law: are the services different?, Review of Industrial Organization 24(3): 301-324.

http://dx.doi.org/10.1023/B:REIO.0000038273.50622.ec

Bannò, M.; Piscitello, L.; Amorim Varum, C. 2014. The impact of public support on SMEs' outward FDI: evidence from Italy, Journal of Small Business Management 52(1): 22-38.

http://dx.doi.org/10.1111/jsbm.12029

Barry, F.; Van Egeraat, C. 2008. The decline of the computer hardware sector: how Ireland adjusted, Quarterly Economic Commentary Spring: 38-57.

Berggren, B.; Olofsson, C.; Silver, L. 2000. Control aversion and the search for external financing in Swedish SMEs, Small Business Economics 15(3): 233-242.

http://dx.doi.org/10.1023/A:1008153428618

Central Statistics Office (CSO). 2013a. International trade in services 2012. Dublin: The Stationery Office.

Central Statistics Office (CSO). 2013b. National income and expenditure 2012. Dublin: The Stationery Office.

Contractor, F. J.; Kundu, S. K.; Hsu, C. C. 2003. A three-stage theory of international expansion: the link between multinationality and performance in the service sector, Journal of International Business Studies 34(1): 5-18. http://dx.doi.org/10.1057/palgrave.jibs.8400003 
Contractor, F. J.; Kumar, V.; Kundu, S. K. 2007. Nature of the relationship between international expansion and performance: the case of emerging market firms, Journal of World Business 42(4): 401-417. http://dx.doi.org/10.1016/j.jwb.2007.06.003

Eickelpasch, A.; Vogel, A. 2009. Determinants of export behaviour of German business services companies. German Institute for Economic Research, Berlin. 876.

European Commission. 2010. Internationalisation of European SMEs [online], [cited 10 January 2014]. Directorate General for Enterprise and Industry, Entrepreneurship Unit, European Commission, Brussels. Available from Internet: http://ec.europa.eu/DocsRoom/documents/10008/ attachments/1/translations/en/renditions/pdf

Forfás. 2011. Statistics at a glance [online], [cited 21 November 2013]. Available from Internet: http://www.forfas.ie/media/ffs111202Statistics_at_a_glance_2011.pdf

Fryges, H.; Vogel, A.; Wagner, J. 2014. The impact of R\&D activities on exports of German business services enterprises: first evidence from a continuous treatment approach, The World Economy 38(4): 716-729. http://dx.doi.org/10.1111/twec.12177

Ganotakis, P.; Love, J. H. 2011. R\&D, product innovation, and exporting: evidence from UK new technology based firms, Oxford Economic Papers 63(2): 279-306.

http://dx.doi.org/10.1093/oep/gpq027

Gleeson, A. M.; Ruane, F. 2006. Export dynamics in small open economies: indigenous Irish manufacturing exports, 1985-2003, Discussion paper No.140, May 2006. Institute for International Integration Studies.

Gourlay, A.; Seaton, J.; Suppakitjarak, J. 2005. The determinants of export behaviour in UK service firms, The Service Industries Journal 25(7): 879-889.

http://dx.doi.org/10.1080/02642060500134154

Harris, R.; Li, Q. C. 2009. Exporting, R\&D, and absorptive capacity in UK establishments, $O x$ ford Economic Papers 61(1): 74-103. http://dx.doi.org/10.1093/oep/gpn011

Hayakawa, K.; Lee, H. H.; Park, D. 2014. Do export promotion agencies increase exports?, The Developing Economies 52(3): 241-261. http://dx.doi.org/10.1111/deve.12048

Irish Exporters Association. 2011. Top 250 exporters annual report. Dublin: Irish Exporters Association.

Johanson, J.; Vahlne, J. E. 1977. The internationalization process of the firm - a model of knowledge development and increasing foreign market commitments, Journal of International Business Studies 8(1): 23-32.

Knight, G. A.; Cavusgil, S. T. 2005. Innovation, organizational capabilities, and the born global firm, Journal of International Business Studies 35(2): 124-141.

http://dx.doi.org/10.1057/palgrave.jibs.8400071

Lawless, M.; McCann, F.; McIndoe Calder, T. 2014. SMEs in Ireland: contributions, credit and economic crisis, Policy Studies 35(5): 435-457. http://dx.doi.org/10.1080/01442872.2014.886681

Lederman, D.; Olarreaga, M.; Payton, L. 2010. Export promotion agencies: do they work?, Journal of Development Economics 91(2): 257-265. http://dx.doi.org/10.1016/j.jdeveco.2009.09.003

Lefebvre, E.; Lefebvre, L. A.; Bourgault, M. 1998. R\&D-related capabilities as determinants of export performance, Small Business Economics 10(4): 365-377.

http://dx.doi.org/10.1023/A:1007960431147

Love, J. H.; Mansury, M. A. 2009. Exporting and productivity in business services: evidence from the United States, International Business Review 18(6): 630-642.

http://dx.doi.org/10.1016/j.ibusrev.2009.08.002

Love J. H.; Roper S.; Hewitt-Dundas, N. 2010. Service innovation, embeddedness and business performance: evidence from Northern Ireland, Regional Studies 44(8): 983-1004.

http://dx.doi.org/10.1080/00343400903401568 
Majocchi, A.; Bacchiocchi, E.; Mayrhofer, U. 2005. Firm size, business experience and export intensity in SMEs: a longitudinal approach to complex relationships, International Business Review 14(6): 719-738. http://dx.doi.org/10.1016/j.ibusrev.2005.07.004

Miles, I. 2005. Innovation in services, in J. Fagerberg, D. C. Mowery, R. Nelson (Eds.). The Oxford handbook of innovation. Oxford: Oxford University Press, 433-458

OECD. 2011. Statistics on international trade in services, Vol. 1. Detailed tables by service category, 2000-2008, 2010 ed. Luxembourg: OECD Publishing.

O'Gorman, C.; Evers, N. 2011. Network intermediaries in the internationalisation of new firms in peripheral regions, International Marketing review 28(4): 340-364.

http://dx.doi.org/10.1108/02651331111149930

Ó Gráda, C. 1997. A rocky road: the Irish economy since the 1920s. Manchester: Manchester University Press.

Ottaviano, G.; Volpe Martincus, C. 2011. SMEs in Argentina: who are the exporters?, Small Business Economics 37(3): 341-361. http://dx.doi.org/10.1007/s11187-009-9244-0

Oviatt, B. M.; McDougall, P. P. 1994. Toward a theory of international new ventures, Journal of International Business Studies 25(1): 45-64. http://dx.doi.org/10.1057/palgrave.jibs.8490193

Papke, L. E.; Wooldridge, J. M. 1996. Econometric methods for fractional response variables with an application to 401(k) plan participation rates, Journal of Applied Econometrics 11(6): 619632. http://dx.doi.org/10.1002/(SICI)1099-1255(199611)11:6<619::AID-JAE418>3.0.CO;2-1

Pires, C. P.; Sarkar, S.; Carvalho, L. 2008. Innovation in services - how different from manufacturing?, The Service Industries Journal 28(10): 1339-1356.

http://dx.doi.org/10.1080/02642060802317812

Raff, H.; Wagner, J. 2014. Foreign ownership and the extensive margins of exports: evidence for manufacturing enterprises in Germany, The World Economy 37(5): 579-591.

http://dx.doi.org/10.1111/twec.12157

Ramalho, E. A.; Ramalho, J. J. S.; Murteira, J. M. R. 2011. Alternative estimating and testing empirical strategies for fractional regression models, Journal of Economic Surveys 25(1): 19-68. http://dx.doi.org/10.1111/j.1467-6419.2009.00602.x

Roper, S.; Love, J. H. 2002. Innovation and export performance: evidence from the UK and German manufacturing plants, Research Policy 31(7): 1087-1102.

http://dx.doi.org/10.1016/S0048-7333(01)00175-5

Roper, S.; Love, J. H.; Hígon, D. A. 2006. The determinants of export performance: evidence for manufacturing plants in Ireland and Northern Ireland, Scottish Journal of Political Economy 53(5): 586-615. http://dx.doi.org/10.1111/j.1467-9485.2006.00396.x

Sousa, C. M. P.; Martinez-López, F. J.; Coelho, F. 2008. The determinants of export performance: a review of the research in the literature between 1998 and 2005, International Journal of Management Reviews 10(4): 343-374. http://dx.doi.org/10.1111/j.1468-2370.2008.00232.x

United States International Trade Commission (USITC). 2010. Small and medium sized enterprises: overview of participation in US exports, Investigation No. 332-508. Washington, DC: USITC Publication 4125.

Wagner, J. 2001. A note on the firm size-export relationship, Small Business Economics 17(4): 229-237. http://dx.doi.org/10.1023/A:1012202405889

Wagner, J. 2014a. Is export diversification good for profitability? First evidence for manufacturing enterprises in Germany, Applied Economics 46(33): 4083-4090.

http://dx.doi.org/10.1080/00036846.2014.950797

Wagner, J. 2014b. Exports, foreign direct investments and productivity: are services firms different?, The Service Industries Journal 34(1): 24-37. http://dx.doi.org/10.1080/02642069.2013.763344 
Wagner, J. 2014c. Credit constraints and margins of import: first evidence for German manufacturing enterprises, Applied Economics 46(3): 294-302. http://dx.doi.org/10.1080/00036846.2 013.839866

Wakelin, K. 1998. Innovation and export behaviour at the firm level, Research Policy 26(7/8): 829-841. http://dx.doi.org/10.1016/S0048-7333(97)00051-6

Westhead, P.; Wright, M.; Ucbasaran, D. 2001. The internationalization of new and small firms, Journal of Business Venturing 16(4): 333-358. http://dx.doi.org/10.1016/S0883-9026(99)00063-4

Zahra, S. 2005. A theory of international new ventures: a decade of research, Journal of International Business Studies 36(1): 20-28. http://dx.doi.org/10.1057/palgrave.jibs.8400118

Ciarán MAC AN BHAIRD, Dr, is a lecturer of Business and Management at Fiontar (Enterprise), Dublin City University and Director of the DCU Student Start-up Accelerator programme. His research interests include capital structure and financial management in medium sized enterprises; angel investing; financing young high-tech firms, particularly cloud computing firms (SAAS); regional development, and public policy related to provision of support to SMEs. He is a board member of the Institute for Small Business and Entrepreneurship, and advises start-ups on a continuous basis.

Declan CURRAN, Dr, is a lecturer of Economics at Dublin City University Business School, prior to which he completed a two-year post-doctoral fellowship in the National Institute for Regional and Spatial Analysis (NIRSA), National University of Ireland, Maynooth. His research interests focus on the empirics of economic growth across regions and within industry sectors, and the application of spatial econometric methods to these issues, as well as quantitative methods for social network analysis. 